\title{
Effect of urea in the diet on ovarian follicular dynamics and plasma progesterone concentration in Alpine goats ${ }^{1}$
}

\author{
Nadja Gomes Alves ${ }^{2}$, Ciro Alexandre Alves Torres ${ }^{2}$, José Domingos Guimarães ${ }^{3}$, Elenice \\ Andrade Moraes ${ }^{2}$, Marcelo Teixeira Rodrigues ${ }^{2}$, Paulo Roberto Cecon ${ }^{4}$, Luciene Lignani \\ Bitencourt $^{3}$, Lincoln da Silva Amorim ${ }^{2}$
}

\footnotetext{
1 Pesquisa financiada pela FAPEMIG.

2 Departamento de Zootecnia, Universidade Federal de Viçosa.

3 Departamento de Medicina Veterinária, Universidade Federal de Viçosa.

${ }^{4}$ Departamento de Ciências Exatas, Universidade Federal de Viçosa.
}

\begin{abstract}
To evaluate the effect of using urea in the diet on ovarian follicular dynamics and plasma urea and progesterone concentration, an experiment was carried out with 29 Alpine goats randomly distributed into four diets, each one containing $0 \%$; $0.73 \% ; 1.46 \%$ or $2.24 \%$ of urea on total dry matter. The follicular dynamics was monitored daily by ultrasonography. The estrous cycles were characterized by occurrence of two, three, four or five follicular waves. The emergence day of the first follicular wave in cycles with two waves, the length of the third wave and the maximum diameter of the largest follicle of the third wave in cycles with three waves presented a quadratic behavior according to the percentage of urea in the diets. In cycles with four waves, the urea intake did not influence the follicular dynamics. The interestrus and interovulatory periods and the luteal and follicular phases length did not differ among treatments. The plasma urea concentration did not differ among diets neither among collection weeks. Plasma progesterone concentration on the estrus day and on the $11^{\text {th }}$ day after estrus presented quadratic behavior, and on the $15^{\text {th }}$ day after estrus, it linearly reduced acording to the percentage of urea in the diets. The supply of urea in diets at levels up to $2.24 \%$ in dietary dry matter did not influence the dry matter intake and the urea plasma concentration. For goats, the emergence day and the length of the waves, the follicular diameter and the plasma progesterone concentration on the estrus day and in the latter stages of diestrus were altered when there was supply of urea in the diet.
\end{abstract}

Key Words: corpus luteum, estrous cycle, follicular development, protein

\section{Introduction}

The use of ultrasonography in reproduction allowed daily monitoring of ovarian follicular development during the estrous cycle, demonstrating clear pattern of growth and regression of antral follicles, with process of recruitment, selection and follicular dominance in cattle (Ginther et al., 1989; Ginther et al., 1996) and in sheep (Ginther et al., 1995; Souza et al., 1997; Evans et al., 2000).

In goats, initial studies using laparoscopy (Camp et al., 1983), laparotomy (Akusu et al., 1986) or examination of ovaries of slaughterhouse (Sureshkumar \& Janakiraman, 1993) did not evaluated so consistently the pattern of follicle growth. Therefore, studies that used ultrasound to monitor follicular dynamics have shown that follicles develop in waves, and there may be two to six follicular waves during the estrous cycle, but with a predominance of two (Amorim et al., 2007) or four waves (Ginther \& Kot, 1994; Castro et al., 1999; Schawarz \& Wierzchós, 2000; Menchaca \& Rubianes, 2002; Tenório Filho et al., 2007).
The studies that investigated the relationship between protein intake and ovarian follicular dynamics are contradictory. Garcia-Bojalil et al. (1998) observed reduction in the number of ovarian follicles and in the maximum diameter of the largest follicle of lactating Holstein cows receiving $15.7 \%$ of rumen-degradable protein (RDP) in the diet, compared to those which received $11.1 \%$ of RDP in the postpartum period. However, diets with $12.3 \%$ or $27.4 \%$ of crude protein (CP) fed to nonlactating Holstein cows (Garcia-Bojalil et al., 1994) or 0.0, $0.7,1.4$ and $2.1 \%$ of urea on the dry matter (DM) fed to Holstein $\times$ Zebu lactating cows (Oliveira, 2004) did not influence the pattern of ovarian follicular growth.

The excess of ammonia or urea can change the hypothalamic-pituitary-gonadal axis by decreasing in amplitude and frequency the pulses of luteinizing hormone (LH, Kaur \& Arora, 1995). In vitro, urea inhibited the binding of ${ }^{125}$ I-human chorionic gonadotropin (HCG) to plasma membrane of bovine corpus luteum (Haour \& Saxena, 1974). Some authors suggested an inverse 
relationship between protein intake and circulating progesterone in cows (Jordan \& Swanson, 1979; Jordan et al., 1983; Sonderman \& Larson, 1989), which could result in reduced fertility because that hormone is essential for early embryonic development and subsequent maintenance of pregnancy.

The objectives of this study were to compare the effect of diets with different percentages of urea on ovarian follicular dynamics, plasma urea and progesterone concentration in Alpine goats during the reproductive season.

\section{Material and Methods}

This study was carried from March to June 2003, in the breeding season, at the Seção de Caprinos in Departamento de Zootecnia at Universidade Federal de Viçosa, Viçosa, Minas Gerais, Brazil.

Twenty-nine non-pregnant and non-lactating Alpine goats with $50.38 \pm 8.96 \mathrm{~kg}$ of body weight were randomly distributed into four treatments and gradually adapted to their diets and urea percentages: $0 \%$ of urea on the DM of diet (control, $n=7$ ), $0.73 \%$ of urea ( $n=7), 1.46 \%$ of urea $(n=7)$, and $2.24 \%$ of urea $(n=8)$.

The diets (Table 1) were formulated according to Agricultural Food Research Council (1993) to supply the requirements of maintenance. The diets with $0 \%, 0.73 \%$, $1.46 \%$ and $2.24 \%$ of urea were isocaloric (1.52 Mcal $/ \mathrm{kg}$ DM in the diet without urea and $1.54 \mathrm{Mcal} / \mathrm{kg} \mathrm{DM}$ in the diets with $0.73 \%, 1.46 \%$ and $2.24 \%$ of urea) and isonitrogenous (14\% CP on the DM) and contained 28.79\%, 38.97\%, $49.50 \%$ and $60.85 \%$ of $\mathrm{CP}$ in the form of non-protein nitrogen (NPN), respectively. The percentages of urea derived NPN

Table 1 - Ingredient and nutrient composition of diets

$\%$ of urea on the dry
matter of the diet

$\begin{array}{llll}0 & 0.73 & 1.46 & 2.24\end{array}$

\begin{tabular}{lcccc}
\hline Ingredient & & & & \\
Corn silage (\% DM) & 81.37 & 75.21 & 72.59 & 69.96 \\
Corn grain ground (\% DM) & - & 10.14 & 16.67 & 23.58 \\
Soybean meal (\% DM) & 17.63 & 12.92 & 8.28 & 3.27 \\
Urea (\% DM) & - & 0.73 & 1.46 & 2.24 \\
Limestone (\% DM) & 1.00 & 1.00 & 1.00 & 0.95 \\
& & & & \\
Nutrient & & & & \\
Dry matter (\% of as fed) & 35.06 & 36.72 & 37.49 & 38.30 \\
Crude protein (\% DM) & 14.00 & 14.00 & 14.00 & 14.00 \\
Ether extract (\% DM) & 2.66 & 2.74 & 2.81 & 2.88 \\
Neutral detergent fiber (\% DM) & 41.59 & 38.51 & 37.21 & 35.90 \\
Ash (\% DM) & 5.98 & 5.50 & 5.15 & 4.74 \\
Non-fibrous carbohydrate (\% DM) & 35.77 & 39.25 & 40.83 & 42.48 \\
\hline${ }^{1}$ Calculated by difference: $100-(\%$ crude protein + \% ether extract + \% neutral \\
detergent fiber +\% ash).
\end{tabular}

on CP were $0 \%, 13 \%, 26 \%$ and $40 \%$ in the diets with $0 \%$, $0.73 \%, 1.46 \%$ and $2.24 \%$ of urea, respectively.

The goats of the same treatment were kept in collective pens and fed corn silage and concentrate according to ingredients percentages in the diets (Table 1), in a total amount of $1 \mathrm{~kg}$ of dry matter/goat daily. The feed was offered twice a day at 8 a.m. and 4 p.m. and the total amount offered was adjusted daily to allow at least $5 \%$ of orts. Water and a commercial mineral salt ${ }^{1}$ (Purinafos Goat, Purina, MG, Brazil) were available ad libitum. Samples of corn silage and orts from each pen were collected daily. Proximate analysis of corn grain ground, soybean meal and composite samples at every three weeks for corn silage and every nine weeks for orts were performed. The samples were dried at $55^{\circ} \mathrm{C}$ for $72 \mathrm{~h}$ and ground through a $1 \mathrm{~mm}$ screen. Dry matter was determined by drying samples at $110^{\circ} \mathrm{C}$ overnight. Crude protein, neutral detergent fiber (NDF), ether extract and ash were analyzed according to AOAC (1995).

Goats were weighed once a week in the morning before feeding and the mean daily body weight calculated. Estrous detection was made by a vasectomized male in each pen twice daily, at 7 a.m. and 4 p.m. for a minimum of 15 minutes. The estrous interval was defined as the number of days between two consecutive estrous.

The follicular dynamic was monitored daily by transrectal ultrasonography during one, two or three consecutive interovulatory periods for each goat, totaling forty-seven estrous cycles. Transrectal ultrasonography of the ovaries was performed by a single operator daily from the day of estrus. The examinations were performed as described by Ginther \& Kot (1994) using a real-time B-mode ultrasound scanner equipped with a $5.0 \mathrm{MHz}$ linear array transducer (Aloka SSD-500, Aloka Co. Ltd, Tokyo, Japan). The 3- and 4- mm follicles had the diameters estimated in real-time to prevent losing identity of follicles during frequent freezing of an image. The diameter of follicles $\geq 5 \mathrm{~mm}$ was determined by the average of its two largest diameters. The location of follicles was sketched on ovarian map relative to each other and to the corpus luteum (CL). Each follicle $\geq 5 \mathrm{~mm}$ was identified by a letter code in the sketch, which was maintained for as long as the follicle was identifiable. After recording locations and diameters, the sketch was compared with that of the previous day. Follicular diameter data were plotted in graphs that showed the profile of growth and regression for each follicle.

\footnotetext{
${ }^{1}$ Guarantee levels by kg: P - 70.0 g, Ca - 210.0 g, Na - 100.0 g, Mg - 5.0 g, S - 10,0 g Co - $25.0 \mathrm{mg}$, Cu - $440.0 \mathrm{mg}$, I - $48.0 \mathrm{mg}$, Mn - $1485.0 \mathrm{mg}$, Se - $20.0 \mathrm{mg}$, Zn $3010.0 \mathrm{mg}, \mathrm{Fe}-340.0 \mathrm{mg}, \mathrm{F}-700.0 \mathrm{mg}$ Maximum, Cr - $6.0 \mathrm{mg}$, Vitamin A 250000 IU, Vitamin D3 - 40000 IU, Vitamin E - 350000 IU.
} 
A follicular wave was defined as a group of follicles which grew at the same time and from which gave rise to one or more follicles $\geq 5 \mathrm{~mm}$ in diameter (Castro et al., 1999). Day of emergence of the wave was the day of emergence of the largest follicle of that wave, and more than one day was allowed for all the follicles of a wave to emerge (Ginther \& Kot, 1994). The day of emergence of the largest follicle was the day that this follicle was $3 \mathrm{~mm}$ in diameter followed by an increase in diameter for $\geq 4 \mathrm{~mm}$ on the following day (Castro et al., 1999). When a follicle was first detected at $\geq 4 \mathrm{~mm}$ diameter, the day of emergence was retrospectively determined, considering a growth rate of $1 \mathrm{~mm} /$ day. The end of wave was the day in which the last follicle in regression of that wave reached $3 \mathrm{~mm}$. The length of follicular wave was the number of days between its emergence and end. Interwave interval was the number of days between the emergence of two successive waves (Castro et al., 1999). Growth phase of the largest follicle was the time taken by that follicle to grow from $3 \mathrm{~mm}$ in diameter to its maximum diameter (Castro et al., 1999). Growth rate (mm/day) of a follicle was calculated by determining the increase of diameter from day of emergence until day of maximum diameter and dividing this by the number of days (Rubianes et al., 1996).

Ovulation was determined by the disappearance of follicles $\geqslant 5 \mathrm{~mm}$ and subsequent detection of CL. The onset of luteal regression was defined as the first day that the area of CL showed progressive reduction. The number of days from ovulation to onset of luteolysis and this to next ovulation were used to define the follicular and luteal phases, respectively (Ginther \& Kot, 1994). The interovulatory interval was defined as the number of days between two consecutive ovulations and was used to define the length of the estrous cycle. When two or three ovulations occurred in the same interovulatory interval, but on different days, the day of the first ovulation was considered the last day of that period.

For urea analysis, blood samples were collected by jugular vein puncture once a week, before feeding in the morning and four hours after it. For progesterone analysis, blood samples were collected on the estrus day (Day 0) and on days 3, 7, 11, 15 and 19 after estrus. Plasma progesterone concentration was determined by solid phase radioimmunoassay (Coat-a-count progesterone kit, DPC, Diagnostic Products Co., Los Angeles, CA, USA). The assay sensitivity was $0.02 \mathrm{ng} / \mathrm{mL}$. Plasma urea concentration was determined by enzymatic-colorimetric method (Urea 500, DOLES Reagents and Equipment for Laboratories LTD, GO, Brazil).
Statistical analyses were performed by using SAEG System for Genetic Analysis and Statistics (UFV, 1997). Body weight and plasma urea concentration were analyzed by response surface methodology. The models were chosen based on the significance of the regression coefficients, using the $t$ test at 5\% probability, the coefficient of determination, and biological phenomenon. Average individual intake of DM and nutrients, ovarian follicular dynamics and plasma progesterone concentration were analyzed by analysis of variance and regression.

\section{Results and Discussion}

The urea addition to the diets did not affect $(\mathrm{P}>0.05)$ the average individual intake, in $\mathrm{kg} / \mathrm{day}$, of $\mathrm{DM}(\hat{\mathrm{Y}}=0.82), \mathrm{CP}$ $(\hat{Y}=0.11)$ and total digestible nutrients $(\hat{Y}=0.57)$, whereas the average individual intake of NDF decreased linearly $\left(\hat{\mathrm{Y}}=0.35-0.02 * * * \mathrm{U}, \mathrm{R}^{2}=0.89, \mathrm{P}<0.001\right)$ and the NFC increased linearly $\left(\hat{\mathrm{Y}}=0.28+0.03 * \mathrm{U}, \mathrm{R}^{2}=0.80, \mathrm{P}<0.05\right)$. The DMintake observed was inferior to that recommended by AFRC (1997) for non-lactating goats, which is $1.20 \mathrm{~kg} /$ day. However, the intake was sufficient to supply the requirements of the animals inasmuch as they did not lose body weight during the experiment. According to NRC (1981), the urea addition to the diet of goats should not exceed 1/3 CP of the diet or more than $50 \%$ of CP of the concentrate. In this study, feeding up to $40 \%$ of CP as urea did not affect the DM intake. Some authors reported that the urea could be supplied in quantities superior to the ones recommended by NRC (1981), without reducing the DM intake (Singhal \& Mudgal, 1980; Fernandez et al., 1997).

The linear regression model which best explained the body weight related to the time (days) was: $\hat{\mathrm{Y}}=49.62+0.02 * * * \mathrm{D}\left(\mathrm{R}^{2}=0.87, \mathrm{P}<0.001\right)$ for goats fed no urea, $\hat{\mathrm{Y}}=50.43+0.04 * * * \mathrm{D}\left(\mathrm{R}^{2}=0.94, \mathrm{P}<0.001\right)$ for goats fed $0.73 \%$ of urea, $\hat{\mathrm{Y}}=49.52+0.06 * * * \mathrm{D}\left(\mathrm{R}^{2}=0.92, \mathrm{P}<0.001\right)$ for goats fed $1.46 \%$ of urea and $\hat{Y}=53.15+0.02 * * * D\left(R^{2}=0.65\right.$, $\mathrm{P}<0.001$ ) for goats fed $2.24 \%$ of urea, showing that daily weight gain was 0.02 to $0.06 \mathrm{~kg}$ during the experimental period.

One goat fed no urea was not evaluated for follicular dynamics throughout the estrous cycle, one that received $0.73 \%$ of urea did not show estrus and one fed $1.46 \%$ of urea showed multiple follicular cysts and were excluded from analysis for interestrus and interovulatory intervals, luteal and follicular phases, ovarian follicular dynamics and urea and progesterone plasma concentration.

From the 47 estrous cycles monitored, 28 (59.57\%) were classified as normal length (17 to 25 days), 7 (14.89\%) as short (<17 days) and $12(25.53 \%)$ as long (>25 days), 
according to Gordon (1997). The normal length cycles were characterized by two $(n=6)$, three $(n=13)$, four $(n=8)$ or five follicular waves $(n=1)$. The number of follicular waves was not affected $(\mathrm{P}>0.05)$ by the urea percentage in the diets, being represented by equation $\hat{Y}=3.14$. One goat fed $0.73 \%$ of urea showed five follicular waves (Table 2) and was excluded from statistical analyses for interestrus and interovulatory intervals, luteal and follicular phases and ovarian follicular dynamics.

In goats with two, three or four follicular waves, the interestrous and interovulatory intervals and the length of follicular and luteal phases did not differ $(\mathrm{P}>0.05)$ among the control goats and those that received urea in diet (Table 3 ). The interestrous and interovulatory intervals observed in this study were similar to that observed by Castro et al. (1999) in Saanen goats, at 20.9 and 20.8 days; and by Menchaca e Rubianes (2001) in Saanen × Anglo Nubian goats, 20.4 and 20 days, respectively. The luteal phase length, determined by the observation of luteal tissue by ultrasonography, was similar to that mentioned by Ginther \& Kot (1994), using the same methodology, and also similar to that observed by Castro et al. (1999) and Menchaca \& Rubianes (2001), based on daily analysis of plasma progesterone (16.3 and 16.0 days, respectively).

In estrous cycles with two follicular waves, the day of emergence of the first follicular wave/largest follicle showed a quadratic response $(\mathrm{P}<0.05)$ as related to urea percent in the diets (Table 4). According to the equation, the lowest value for the day of emergence of the first follicular wave/ largest follicle (-0.51) occurred with intake of $1.23 \%$ of urea. In estrous cycles with three follicular waves, the length of the third wave and the maximum diameter of its largest follicle showed a quadratic response $(\mathrm{P}<0.01)$ as related to urea percent in the diets. According to the equations, the

Table 2 - Follicular dynamics characteristics in one goat with five follicular waves during the estrous cycle of 19 days

\begin{tabular}{lccccc}
\hline & \multicolumn{5}{c}{ Follicular wave } \\
\cline { 2 - 6 } & $1^{\text {st }}$ & $2^{\text {st }}$ & $3^{\text {st }}$ & $4^{\text {st }}$ & $5^{\text {st }}$ \\
\hline $\begin{array}{l}\text { Day of emergence of } \\
\text { wave/largest follicle }\end{array}$ & -2 & 2 & 6 & 9 & 14 \\
$\begin{array}{l}\text { Wave length (days) } \\
\begin{array}{l}\text { Maximum diameter of the } \\
\text { largest follicle (mm) }\end{array}\end{array}$ & 7 & 11 & 9 & 10 & 5 \\
$\begin{array}{l}\text { Day of maximum diameter of } \\
\text { the largest follicle }\end{array}$ & 5.5 & 6.5 & 7.0 & 7.5 & 9.0 \\
$\begin{array}{l}\text { Growth phase of the largest } \\
\text { follicle (days) }\end{array}$ & 2 & 4 & 8 & 12 & 19 \\
$\begin{array}{l}\text { Growth rate of largest } \\
\text { follicle (mm/day) }\end{array}$ & 4 & 2 & 2 & 3 & 5 \\
\hline
\end{tabular}

highest values for the third wave length (8.97 days) and for the maximum diameter of its largest follicle $(9.60 \mathrm{~mm})$ occurred with the intake of $1.17 \%$ and $1.14 \%$ of urea in the diets, respectively. In estrous cycles with four follicular waves, the urea percent in the diet did not influence $(\mathrm{P}>0.05)$ the follicular dynamics.

The days of emergence of the follicular waves in the cycles with two, three or four waves were similar to those reported by Castro et al. (1999) in Saanen goats. However, in the cycles with four waves, the second, third and fourth waves emerged later than those reported by Ginther \& Kot (1994), who observed the emergence of waves between days - 2 and 1 (first wave); 2 and 5 (second wave); 6 and 9 (third wave) and 10 and 15 (fourth wave). In Polish goats, Schwarz \& Wierzchos (2000) observed the emergence of the five follicular waves in the days $-1,4,7,11$ and 15 of the estrous cycle and therefore, one to two days after the observed in this study.

According to this study, Ginther \& Kot et al. (1994) also reported a greater emergence interval between waves one and two (3.4), comparing to the emergence interval between waves two and three (2.8 days) and three and four (2.3 days). Similarly, Castro et al. (1999) observed longer period between the emergence of the waves one and two (7.3 days) than between the waves two and three (4.0 days) and waves three and four (3.8 days). According to these authors, the emergence interval of the follicular waves during the luteal phase when the plasma progesterone concentration is high, is greater than the emergence interval of the waves during the follicular phase.

The diameters of the largest follicle from the first and ovulatory waves of the cycles with three and four waves were higher than the values observed in the intermediary waves. Ginther \& Kot (1994) also observed the greatest diameters of the dominant follicles from the first and fourth waves and Castro et al. (1999) observed the greatest diameters of the dominant follicles from the first, third and fourth waves, in comparison to that of the second wave. According to these authors, the smallest diameter reached by the largest follicle from the second wave could be attributed to the negative influence of the high circulating progesterone concentration during its development. Studies with ewes reported a negative correlation between high plasma progesterone concentration and the maximum diameter from the largest follicle in the beginning of the luteal phase (Rubianes et al., 1996). Progesterone acting on the hypothalamus-hypophysis axis inhibits the frequency of LH pulses, culminating in lower follicular development rate (Savio et al., 1993).

The plasma urea concentration before feeding in the morning and four hours after $(\hat{Y}=43.66$ and $\hat{Y}=48.08 \mathrm{mg} / \mathrm{dL}$, 
respectively), was not affected ( $\mathrm{P}>0.05$ ) by urea percent in the diet or by experimental weeks. In the ruminants, a fraction of dietary CP is degraded in rumen with consequent release of ammonia, which is used for the synthesis of microbial protein. If formed in excess, the ammonia is directly absorbed by the rumen wall and transported to liver, where it is converted to urea, which is eliminated by urine (Hameyer \& Martens, 1980). When the detoxification capacity of the liver is exceed, the ammonia and urea plasma concentration increases rapidly. In this study, the addition of urea in the

Table 3 - Adjusted regression equations of the interestrous interval, interovulatory interval, luteal and follicular phases in goats fed urea in the diet

\begin{tabular}{|c|c|c|c|c|c|c|c|c|c|}
\hline \multirow[b]{2}{*}{ Parameters } & \multicolumn{3}{|c|}{ Two waves $(n=6)$} & \multicolumn{3}{|c|}{ Three waves $(n=13)$} & \multicolumn{3}{|c|}{ Four waves $(n=8)$} \\
\hline & Equation & $\mathrm{R}^{2}$ & $\mathrm{P}$ & Equation & $\mathrm{R}^{2}$ & $\mathrm{P}$ & Equation & $\mathrm{R}^{2}$ & $\mathrm{P}$ \\
\hline Interestrous interval $^{1}$ & $\hat{\mathrm{Y}}=20.50$ & - & - & $\hat{Y}=21.23$ & - & - & $\hat{Y}=21.87$ & - & - \\
\hline Interovulatory interval $^{1}$ & $\hat{Y}=20.17$ & - & - & $\hat{Y}=21.38$ & - & - & $\hat{Y}=21.87$ & - & - \\
\hline Luteal phase ${ }^{1}$ & $\hat{\mathrm{Y}}=17.83$ & - & - & $\hat{Y}=18.67$ & - & - & $\hat{\mathrm{Y}}=18.87$ & - & - \\
\hline Follicular phase ${ }^{1}$ & $\hat{\mathrm{Y}}=2.33$ & - & - & $\hat{\mathrm{Y}}=2.91$ & - & - & $\hat{\mathrm{Y}}=3.00$ & - & - \\
\hline
\end{tabular}

${ }^{1}$ Days

Table 4 - Adjusted regression equations of the follicular dynamics characteristics of goats fed urea in the diet

\begin{tabular}{|c|c|c|c|c|c|c|}
\hline Parameters & \multicolumn{2}{|c|}{ Two waves $(n=6)$} & \multicolumn{2}{|c|}{ Three waves $(n=13)$} & \multicolumn{2}{|c|}{ Four waves $(n=8)$} \\
\hline \multicolumn{7}{|c|}{$\begin{array}{l}\text { Day of emergence } \\
\text { of wave or largest follicle }\end{array}$} \\
\hline $1^{\text {st }}$ wave & $\hat{\mathrm{Y}}=3.57-6.64^{\text {n.s. }} \cdot \mathrm{U}+2.70 * \mathrm{U}^{2}$ & 0.71 & $\hat{\mathrm{Y}}=0.77$ & & $\hat{\mathrm{Y}}=0.25$ & \\
\hline $2^{\text {nd }}$ wave & $\hat{\mathrm{Y}}=11.33$ & - & $\hat{\mathrm{Y}}=8.07$ & & $\hat{\mathrm{Y}}=6.12$ & \\
\hline $3^{\text {rd }}$ wave & & & $\hat{\mathrm{Y}}=14.84$ & - & $\hat{\mathrm{Y}}=12.0$ & \\
\hline \multicolumn{7}{|c|}{ Wave length (days) } \\
\hline $1^{\text {st }}$ wave & $\hat{\mathrm{Y}}=12,67$ & - & $\hat{\mathrm{Y}}=12.23$ & - & $\hat{\mathrm{Y}}=11.50$ & - \\
\hline $2^{\text {nd }}$ wave & $\hat{\mathrm{Y}}=9.33$ & - & $\hat{\mathrm{Y}}=10.46$ & - & $\hat{\mathrm{Y}}=9.87$ & - \\
\hline $3^{\text {rd }}$ wave & & & $\hat{\mathrm{Y}}=5.77+5.47^{\text {n.s. }} \cdot \mathrm{U}-2.34 * * \mathrm{U}^{2}$ & 0.56 & $\hat{\mathrm{Y}}=8.50$ & - \\
\hline $4^{\text {th }}$ wave & & & & & $\hat{\mathrm{Y}}=6.25$ & - \\
\hline \multicolumn{7}{|c|}{ Interwave interval (days) } \\
\hline $1^{\text {st }}-2^{\text {nd }}$ & $\hat{\mathrm{Y}}=9.83$ & - & $\hat{\mathrm{Y}}=7.31$ & - & $\hat{\mathrm{Y}}=5.87$ & - \\
\hline $1^{\text {st }}$ wave & $\hat{\mathrm{Y}}=8.66$ & - & $\hat{\mathrm{Y}}=7.92$ & - & $\hat{\mathrm{Y}}=7.50$ & - \\
\hline $2^{\text {nd }}$ wave & $\hat{\mathrm{Y}}=8.58$ & - & $\hat{\mathrm{Y}}=7.00$ & - & $\hat{\mathrm{Y}}=7.12$ & - \\
\hline $3^{\text {rd }}$ wave & & & $\hat{\mathrm{Y}}=7.61+3.49^{\text {n.s. }} \cdot \mathrm{U}-1.53 * * \mathrm{U}^{2}$ & 0.90 & $\hat{Y}=6.87$ & - \\
\hline $4^{\text {th }}$ wave & & & & & $\hat{\mathrm{Y}}=8.19$ & - \\
\hline \multicolumn{7}{|c|}{$\begin{array}{l}\text { Day of maximum diameter of } \\
\text { the largest follicle }\end{array}$} \\
\hline $1^{\text {st }}$ wave & $\hat{\mathrm{Y}}=7.00$ & - & $\hat{\mathrm{Y}}=5.61$ & - & $\hat{\mathrm{Y}}=5.25$ & - \\
\hline $2^{\text {nd }}$ wave & $\hat{\mathrm{Y}}=19.16$ & - & $\hat{\mathrm{Y}}=11.92$ & - & $\hat{\mathrm{Y}}=10.62$ & - \\
\hline $3^{\text {rd }}$ wave & & & $\hat{\mathrm{Y}}=20.61$ & - & $\hat{\mathrm{Y}}=15.50$ & - \\
\hline $4^{\text {th }}$ wave & & & & & $\hat{\mathrm{Y}}=21.37$ & - \\
\hline \multicolumn{7}{|c|}{$\begin{array}{l}\text { Growth phase of the largest } \\
\text { follicle (days) }\end{array}$} \\
\hline $3^{\text {rd }}$ wave & & & $\hat{\mathrm{Y}}=1.07$ & - & $\hat{\mathrm{Y}}=1.14$ & - \\
\hline $4^{\text {th }}$ wave & & & & & $\hat{\mathrm{Y}}=1.06$ & - \\
\hline
\end{tabular}

$* \mathrm{P}<0.05$, $* * \mathrm{P}<0.01$; n.s.: non-significant at $5 \%$ of the probability by t test. 
diet until 2.24\% on DM did not cause a proportional increase in plasma urea concentration. It is possible that the animals have adapted to the high urea percent in the diet, altering the activity of ruminal microorganisms and increasing the activity of hepatic enzymes related to the urea cycle. Payne \& Morris (1969) observed greater hepatic concentration of the urea cycle enzymes, arginine synthetase, ornithine carbamyltransferase, and arginase, in sheep fed high-protein diet than in sheep fed low-protein diet.

Composition of nutrients of the diets could be related to the similarity observed in the plasma urea concentration among goats from the different treatments. The starch from corn grain ground present in increased amounts in the diets offered to goats that received $0.73 \%$ of urea (10.14\%), $1.46 \%$ of urea (16.67\%) and $2.24 \%$ of urea (23.56\%) on the DM of diet allowed better conversion of NPN from urea to microbial protein. However, in studies with heifers (Gath et al., 1999; Kenny et al., 2002), lactating cows (Dawuda et al., 2002), ewes (McEvoy et al., 1997; Fahey et al., 2001) and goats (Fernandez et al., 1997), the addition of urea to the diets resulted in increased plasma urea concentration. The observed differences among studies may be related to the nutrient composition of diets, the physiological status of animals and the time of blood collection after feeding.

Plasma progesterone concentration data of one estrous cycle of one goat fed $2.24 \%$ of urea was excluded from the statistical analysis because the hormonal analysis was not performed in all days of blood collection. Plasma progesterone concentration on the estrus day $(\mathrm{P}<0.05)$ and 11 days later $(\mathrm{P}<0.01)$ showed a quadratic response to urea percentage in the diets (Table 5). The highest plasma progesterone concentration on the estrus day $(0.2 \mathrm{ng} / \mathrm{mL})$ and on the day 11 after estrus ( $8.55 \mathrm{ng} / \mathrm{mL}$ ) occurred with the intake of $1.36 \%$ and $0.95 \%$ of urea in the diets, respectively. In these specific phases of the estrous cycle, the addition of urea to the diet in levels higher than those resulted in reduction in the plasma progesterone concentration. On

Table 5 - Adjusted regression equations of the plasma progesterone concentration $(\mathrm{ng} / \mathrm{mL})$ on the estrus day and on the days 3, 7, 11, 15 and 19 after estrus in goats fed urea in the diet

\begin{tabular}{lccc}
\hline Day & Adjusted equation & $\mathrm{R}^{2}$ & $\mathrm{P}$ \\
\hline 0 (Estrous) & $\hat{\mathrm{Y}}=0.07+0.19 \mathrm{U}-0.07 * \mathrm{U}^{2}$ & 0.96 & 0.05 \\
3 & $\hat{\mathrm{Y}}=1.39$ & - & $\mathrm{ns}$ \\
7 & $\hat{\mathrm{Y}}=5.75$ & - & $\mathrm{ns}$ \\
11 & $\hat{\mathrm{Y}}=7.16+2.93 \mathrm{U}-1.54 * * \mathrm{U}^{2}$ & 0.99 & 0.01 \\
15 & $\hat{\mathrm{Y}}=8.29-0.98 * \mathrm{U}$ & 0.58 & 0.05 \\
19 & $\hat{\mathrm{Y}}=2.48$ & - & $\mathrm{ns}$ \\
\hline ns: non-significant at $5 \%$ of the probability by t test. & &
\end{tabular}

day 15 after estrus, the plasma progesterone concentration reduced linearly $(\mathrm{P}<0.05)$ as the urea percent in the diets increased. Jordan \& Swanson (1979) observed that plasma progesterone concentration on the $14^{\text {th }}$ day of the first postpartum estrous cycle was higher in cows which received $12.7 \%$ of CP versus those which received $16.3 \%$ and $19.3 \%$ of CP. Similarly, Jordan et al. (1983) observed higher plasma progesterone concentration on the $15^{\text {th }}$ day of the estrous cycle in Holstein cows fed $12 \%$ of CP, during the postpartum period, compared to those receiving $23 \%$ of CP. On days 3 , 7 and 19 after estrus, the plasma progesterone concentration was not affected $(\mathrm{P}>0.05)$ by urea in the diets.

\section{Conclusions}

The supply of urea in the diets up to 2.24\% in DM does not influence the DM intake, body weight and the urea plasma concentration. However, the day of emergence and the length of the follicular waves, the follicular diameter and the plasma progesterone concentration on the estrus day and in the latter stages of diestrus are altered. Given its potential influence on follicular development and in reducing the plasma progesterone concentration during diestrus, the urea should not be added in the diet of nonpregnant and non-lactating goats.

\section{Acknowledgements}

This work was supported by Departamento de Zootecnia at Universidade Federal de Viçosa (Viçosa, MG, Brazil), FAPEMIG (Fundação de Apoio à Pesquisa do Estado de Minas Gerais) and CNPq (Conselho Nacional de Desenvolvimento Científico e Tecnológico).

\section{References}

AGRICULTURAL AND FOOD RESEARCH COUNCIL - AFRC. Energy and protein requirements of ruminants. Wallingford: Commonwealth Agricultural Bureaux International, 1993. 159p.

AGRICULTURAL AND FOOD RESEARCH COUNCIL - AFRC. The Nutrition of Goats. Nutrition Abstract Reviews (Series B), v.67, p.826-844, 1997.

AKUSU, M.O.; OSUAGWUH, A.I.A.; AKPOKODJE, J.U. et al. Ovarian activities of the West African dwarf goat (Capra hircus) during estrus. Journal of Reproduction and Fertility, v.78 p.459-462, 1986.

AMORIM, E.A.M.; TORRES, C.A.A.; AMORIM, L.S. et al. Follicular dynamics of lactating Toggenburg does treated with recombinant bovine somatotropin. Brazilian Journal of Veterinary and Animal Science, v.59, p.1500-1508, 2007.

ASSOCIATION OF OFFICIAL ANALYTICAL CHEMISTRY AOAC. Official methods of analysis. 16.ed. Arlington: AOAC International, 1995. 1025p. 
CAMP, J.C.; WILDT, D.E.; HOWARD, P.K. et al. Ovarian activity during normal and abnormal length estrous cycles in the goat. Biology of Reproduction, v.28, p.673-681, 1983.

CASTRO, T.; RUBIANES, E.; MENCHACA, A. et al. Ovarian dynamics, serum estradiol and progesterone concentrations during the interovulatory interval in goats. Theriogenology, v.52, p.399-411, 1999.

DAWUDA, P.M.; SCARAMUZZI, R.J.; LEESE, H.J. et al. Effect of timing of urea feeding on the yield and quality of embryos in lactating dairy cows. Theriogenology, v.58, p.1443-1455, 2002.

EVANS, A.C.O.; DUFFY, P.; HYNES, N. et al. Waves of follicle development during the estrus cycle in sheep. Theriogenology, v.53, p.699-715, 2000.

FAHEY, J.; BOLAND, M.P.; O'CALLAGHAN, D. The effects of dietary urea on embryo development in superovulated donor ewes and on early embryo survival and development in recipient ewes. Animal Science, v.72, p.395-400, 2001.

FERNANDEZ, J.M.; SAHLU, T.; LU, C.D. et al. Production and metabolic aspects of nonprotein nitrogen incorporation in lactation rations of dairy goats. Small Ruminant Research, v.26, p.105-113, 1997.

GARCIA-BOJALIL, C.M.; STAPLES, C.R.; THATCHER, W.W. et al. Protein intake and development of ovarian follicles and embryos of superovulated nonlactating dairy cows. Journal of Dairy Science, v.77, p.2537-2548, 1994.

GARCIA-BOJALIL, C.M.; STAPLES, C.R.; RISCO, C.A. et al. Protein degradability and calcium salts of long-chain fatty acids in the diets of lactating dairy cows: reproductive responses. Journal of Dairy Science, v.81, p.1385-1395, 1998.

GATH, V.; LONERGAN, P.; BOLAND, M.P. et al. Effects of diet type on establishment of pregnancy and embryo development in beef heifers. Theriogenology, v.51, p.224, 1999.

GINTHER, O.J.; KOT, K. Follicular dynamics during the ovulatory season in goats. Theriogenology, v.42, p.987-1001, 1994.

GINTHER, O.J.; KOT, K.; WILTBANK, M.C. Associations between emergence of follicular waves and fluctuations in FSH concentrations during the estrous cycle in ewes. Theriogenology, v.43. p.689-703, 1995.

GINTHER, O.J.; KNOPF, L.; KASTELIC, J.P. Temporal associations among ovarian events in cattle during oestrous cycle with two or three follicular waves. Journal of Reproduction and Fertility, v.87, p.223-230, 1989

GINTHER, O.J.; WILTBANK, M.C.; FRICHE, P.M. et al. Selection of the dominant follicle in cattle. Biology of Reproduction, v.55, p.1187-1194, 1996.

GORDON, I. Artificial Control of oestrus and breeding activity in goats. In: ___ Controlled reproduction in sheep \& goats. New York: CAB International, 1997. p.374-397.

HAOUR, F.; SAXENA, B.B. Characterization and solubilization of gonadotropin receptor of bovine corpus luteum. The Journal of Biological Chemistry, v.249, p.2195-2205, 1974.

HARMEYER, J.; MARTENS, H. Aspects of urea metabolism in ruminants with reference to the goat. Journal of Dairy Science, v.63, p.1707-1728, 1980.

JORDAN, E.R.; CHAPMAN, T.E.; HOLTAN, D.W. Relationship of dietary crude protein to composition of uterine secretions and blood in high-producing postpartum dairy cows. Journal of Dairy Science, v.66, p.1854-1862, 1983.

JORDAN, E.R.; SWANSON, L.V. Serum progesterone and luteinizing hormone in dairy cattle fed varying levels of crude protein. Journal Animal Science, v.48, p.1154-1158, 1979.
KAUR, H.; ARORA, S.P. Dietary effects on ruminant livestock reproduction with particular reference to protein. Nutrition Research Reviews, v.8, p.121-136, 1995.

KENNY, D.A.; BOLAND, M.P.; DISKIN, M.G. et al. Effect of rumen degradable protein with or without fermentable carbohydrate supplementation on blood metabolites and embryo survival in cattle. Animal Science, v.74, p.529-537, 2002.

MCEVOY, T.G.; ROBINSON, J.J.; AITKEN, R.P. et al. Dietary excesses of urea influence the viability and metabolism of preimplantation sheep embryos and may affect fetal growth among survivors. Animal Reproduction Science, v.47, p.71-90, 1997.

MENCHACA, A.; RUBIANES, E. Effect of high progesterone concentrations during the early luteal phase on the length of the ovulatory cycle of goats. Animal Reproduction Science, v.68, p.69-76, 2001.

MENCHACA, A.; RUBIANES, E. Relation between progesterone concentrations during the early luteal phase and follicular dynamics in goats. Theriogenology, v.57, p.1411-1419, 2002.

NATIONAL RESEARCH COUNCIL - NRC. Nutrient requirements of goats: angora, dairy, and meat goats in temperate and tropical countries. Washington: National Academy Press, 1981. 91p.

OLIVEIRA, M.M.N.; TORRES, C.A.A.; VALADARES FILHO, S.C. et al. Urea for postpartum dairy cows: productive and reproductive performance. Brazilian Journal of Animal Science, v.33, suppl.3, p.2266-2273, 2004.

PAYNE, E.; MORRIS, J.G. The effect of protein content of the diet on the rate of urea formation in sheep liver. Biochemistry Journal, v.113, p.659-662, 1969.

RUBiANES, E.; CASTRO, T.; CARBAJAL, B. Effect of high progesterone levels during the growing phase of the dominant follicle of wave 1 in ultrasonically monitored ewes. Canadian Journal of Animal Science, v.76, p.473-475, 1996.

SAVIO, J.D.; THATCHER, W.W.; BADINGA, L. et al. Regulation of dominant follicle turnover during the oestrous cycle in cows. Journal of Reproduction and Fertility, v.97, p.197-203, 1993.

SCHWARZ, T.; WIERZCHOS, E. Relationship between FSH and ovarian follicular dynamics in goats during the estrous cycle. Theriogenology, v.53, p.381, 2000.

SINGHAL, K.K.; MUDGAL, V.D. Comparative study of urea and biuret feeding on nutrient utilization and milk production in goats. Indian Journal of Animal Science, v.33, p.161, 1980.

SONDERMAN, J.P.; LARSON, L.L. Effect of dietary protein and exogenous gonadotropin-releasing hormone on circulating progesterone concentrations and performance of Holstein cows. Journal of Dairy Science, v.72, p.2179-2183, 1989.

SOUZA, C.L.H.; BRUCE, K.; CAMPBELL, K. et al. Follicular dynamics and ovarian steroids secretion in sheep during the follicular and early luteal phases of the estrous cycle. Biology of Reproduction, v.56, p.483-488, 1997.

SURESHKUMAR, P.K.; JANAKIRAMAN, K. Histomorphological changes of the caprine ovary relative to the stages of the estrous cycle. Small Ruminant Research, v.12, p.287-300, 1993.

TENÓRIO FILHO, F.; SANTOS, M.H.B.; CARRAZZONI, P.G. et al. Follicular dynamics in Anglo-Nubian goats using transrectal and transvaginal ultrasound. Small Ruminant Research, v.72, p.51-56, 2007.

UNIVERSIDADE FEDERAL DE VIÇOSA - UFV, 1997. System for Genetic Analysis and Statistics. Version 8.0. Viçosa, MG, 2000. 142p. 